\author{
Agata Kozioła) \\ (D) https://orcid.org/0000-0002-0062-9429
}

\title{
Glosa do postanowienia Sądu Najwyższego Z dnia 23 marca 2016 r., sygn. akt: III CZP 112/15
}

\begin{abstract}
The role of art. $57 \S 1$ of Polish Family and Guardianship Code in proceedings concerning international divorce is disputed and gives rise to many questions concerning its nature. The provision, addressed to the Polish courts dealing with divorce cases, obliges the seized court to rule on fault of spouses in the breakdown of marriage. It may then seem to remain unclear if the court shall apply art. $57 \S 1$ when the law applicable to divorce does not state for fault based grounds for dissolution of marriage, while the legal order applicable to maintenance obligation between former spouses requires, among other prerequisites, that the fault of the former spouse obliged to alimony is declared in court proceedings.

This paper analyses the judgement of Polish Supreme Court from $23^{\text {rd }}$ of March 2016, in which this issue was raised. The Author rejects the opinion of Supreme Court that the provision in question has a procedural nature. The view, that it constitutes an example of overriding mandatory provision should also be denied. As a provision of double nature: material and procedural, it should be applied by Polish courts as an instrument that enables to rule on fault in all those cases when applicable law provides for fault grounds for divorce; it should be also applied by foreign court deciding on dissolution of marriage when Polish law is applicable.
\end{abstract}

Keywords: significance of fault in divorce proceedings — international divorce - fault and no-fault based grounds for divorce - prerequisites of maintenance obligation towards former spouse after divorce - law applicable to maintenance obligation between divorced spouses — private international law — international family law

a) Dr, Uniwersytet Ślaski w Katowicach. 


\section{Glosa}

Postanowienie Sądu Najwyższego będące przedmiotem niniejszego opracowania zasługuje na uwagę $\mathrm{z}$ tego względu, że skupia w sobie istotne zagadnienia $\mathrm{z}$ zakresu szeroko rozumianego prawa prywatnego międzynarodowego. Na pierwszy plan wysunięto problematykę dotycząca kolizyjnego prawa rodzinnego, w tym przede wszystkim odnoszaca się do rozwiązania małżeństwa i obowiązku alimentacyjnego między rozwiedzionymi małżonkami. Sąd Najwyższy wiele uwagi poświęcił również zagadnieniom związanym $\mathrm{z}$ uznaniem orzeczenia pochodzącego od sądu lub organu państwa niebędącego członkiem Unii Europejskiej. W tle wybrzmiewają też bardziej ogólne rozważania, majace za przedmiot podstawowe (co nie znaczy: proste) instytucje prawa prywatnego międzynarodowego, jak kwalifikacja i dostosowanie czy też analiza przesłanek dopuszczenia do głosu przepisów imperatywnych pochodzacych z innego systemu prawnego niż ten, który występuje w roli miarodajnego statutu.

Glosowane orzeczenie zapadło w następujacymm stanie faktycznym. Powódka, będąca obywatelką polską, oraz pozwany, obywatel Szwecji, w dniu 21 czerwca 2008 r. w Polsce zawarli związek małżeński. Po ślubie strony zamieszkały w Norwegii. W lipcu 2011 r. pozwany zdecydował o zakończeniu małżeństwa, składając wniosek o orzeczenie separacji, w następstwie czego 1 listopada 2011 r. Naczelnik Okręgu T. w Norwegii wydał postanowienie o separacji małżonków. W dniu 10 marca 2012 r. urodziła się córka stron, 20 lipca 2012 r. zaś powódka wniosła o rozwód przed sądem polskim. W dniu 20 czerwca 2014 r. Urząd Wojewódzki w O. w Norwegii orzekł o rozwodzie stron z moca od 7 stycznia 2014 r. Z kolei wyrokiem z dnia 4 lipca 2014 r. Sąd Okręgowy w W. wydał wyrok rozwiązujacy małżeństwo bez orzekania o winie którejkolwiek ze stron. Powódka wniosła apelację od wyroku Sądu Okręgowego w W., zaskarżając go w zakresie, w jakim Sąd Okregowy odstapił od orzekania o winie, jak też w odniesieniu do władzy rodzicielskiej w stosunku do córki stron oraz w przedmiocie rozstrzygnięcia o obowiązku alimentacyjnym powoda zarówno względem córki stron, jak i powódki. Rozpoznając apelację, Sąd Apelacyjny powziął poważne wątpliwości prawne, którym dał wyraz w postanowieniu z dnia 8 września 2015 r., występując z przedstawionym w glosowanym orzeczeniu pytaniem prawnym, którego treść brzmi następująco:

Czy w sprawie o rozwiązanie związku małżeńskiego przez rozwód, przy stosowaniu przez są polski jako prawa właściwego prawa obcego, które nie przewiduje orzekania o winie w rozkładzie pożycia 
stron, należy na mocy art. 8 ust. 2 ustawy z dnia 4 lutego 2011 r. prawo prywatne międzynarodowe (Dz.U. 2011.80.432 j.t. ze zm.) uwzględnić przepis art. $57 \S 1$ k.r.o. jako przepis, który stosuje się bez względu na to, jakiemu prawu oceniany stosunek prawny (stosunek małżeństwa) podlega?

Wśród zagadnień będących przedmiotem rozstrzygnięcia $\mathrm{w}$ sprawie, której dotyczy glosowane orzeczenie, na czoło wysuwa się problematyka związana z ustaleniem prawa właściwego do oceny obowiązku alimentacyjnego między rozwiedzionymi małżonkami w sytuacji, gdy po rozwiązaniu małżeństwa nie mają oni miejsca zwykłego pobytu na terytorium tego samego państwa. W dalszej kolejności Sąd Najwyższy wypowiedział się w przedmiocie uznania orzeczenia rozwodowego pochodzacego od sądu lub organu państwa, które nie jest członkiem Unii Europejskiej, wskazując z jednej strony podstawę prawną takiego uznania, a z drugiej podkreślając, że żaden z sądów obu instancji orzekających w sprawie nie zbadał, czy orzeczenie wydane w dniu 20 czerwca 2014 r. przez Urząd Wojewódzki w O. w Norwegii podlega uznaniu na terytorium naszego państwa. Jedynie pobieżnie zasygnalizowano, w jakim kierunku - w ocenie Sądu Najwyższego - zmierzać powinno rozstrzygnięcie kwestii leżącej u podstaw przedstawionego przez Sąd Apelacyjny zagadnienia budzacego poważne watpliwości prawne, a to z uwagi na fakt, że konieczność takiego rozstrzygnięcia może się zaktualizować w postępowaniu, którego dotyczy glosowane orzeczenie jedynie wówczas, gdy ostatecznie przesądzona zostanie sprawa uznania orzeczenia organu norweskiego.

To ostatnie zagadnienie, mimo że w glosowanym orzeczeniu potraktowane zostało ubocznie, zasługuje na szersze omówienie. Innymi słowy, wyjaśnienia wymaga rola, jaka art. $57 \S 1$ k.r.o. odgrywa nie tylko z perspektywy polskiego prawa materialnego, ale również - a może przede wszystkim - przez pryzmat prawa prywatnego międzynarodowego. Konieczność uważnego rozważenia postawionego przez orzekający w omawianej sprawie Są Apelacyjny pytania wynika ze znaczenia, jakie przypisuje się winie w rozkładzie pożycia małżeńskiego (zerwaniu więzi małżeńskich) w prawodawstwie niektórych państw w odniesieniu do dalszych skutków rozwiązania małżeństwa, w szczególności w zakresie obowiązku alimentacyjnego między rozwiedzionymi małżonkami. Należy pamiętać, że w poszczególnych systemach prawnych różnie definiuje się przesłanki rozwiązania małżeństwa, co w szczególności dotyczy nadawania w tej mierze (w różnym stopniu) doniosłości winie w rozkładzie pożycia albo całkowitego uniezależnienia dopuszczalności rozwodu od oceny 
zachowania małżonków ${ }^{1}$, co $\mathrm{w}$ wielu przypadkach skutkuje trudnościami w orzekaniu o ubocznych następstwach rozwodu. Daleko idące komplikacje moga wystapić przede wszystkim wówczas, gdy prawem właściwym do rozwiązania małżeństwa jest prawo, w którym rozwód wymaga zaistnienia przesłanek o charakterze obiektywnym, nienacechowanych zawinieniem (np. w postaci życia małżonków w rozłączeniu przez określony czas przed wystapieniem z żądaniem rozwiązania małżeństwa czy też samego złożenia wniosku o rozwód przez małżonków), podczas gdy prawo występujące $\mathrm{w}$ roli statutu miarodajnego do oceny danego skutku rozwodu uzależnia ten skutek od stwierdzonej na etapie postępowania o rozwiązanie małżeństwa ${ }^{2}$ winy małżonka w rozkładzie pożycia. Pojawić się więc musi $\mathrm{w}$ tym miejscu pytanie o możliwość stosowania lub uwzględniania $\mathrm{w}$ postępowaniu o rozwiązanie małżeństwa pochodzących z prawa innego niż właściwe tych rozwiązań prawnych, które służą ustaleniu zawinienia małżonków.

Do tego rodzaju zetknięcia się dwóch systemów prawnych o odmiennej koncepcji co do roli winy w rozwodzie i wynikajacych z jej ustalenia następstw doszło w sprawie, w której Sąd Najwyższy wydał glosowane orzeczenie. Należy podkreślić, że Sąd Najwyższy odrzucił prezentowany przez pełnomocnika powódki pogląd, zgodnie z którym art. $57 \S 1$ k.r.o. ma charakter wymuszajacy swoje zastosowanie w rozumieniu art. 8 ust. 1 p.p.m. Sąd Najwyższy stanął na stanowisku, że art. $57 \S 1$ k.r.o. jest normą wchodzaca w skład legi fori processualis i jako taka podlega stosowaniu w każdej sprawie o rozwód toczącej się przed sądem polskim, w której zgodnie z prawem właściwym orzec należy o winie małżonków.

${ }^{1}$ Zob. m.in.: M. Antokolskaia: Divorce law in a European perspective. In: European Family Law. Vol. 3: Family Law in European Perspective. Ed. J.M. Scherpe. Cheltenham, Northampton, 2016, s. 55; Y. Bernand, in: La rupture de marriage en droit compare. Éd. H. Fulchiron. Paris 2015, s. 42; P. Franzina: The law applicable to divorce and legal separation under Regulation (EU) no. 1259/2010 of 20 december 2010. „Cuadernos de Derecho Transnacional” 2011, no. 2, s. 127; H. Bos se-Platière: Le droit français du divorce. In: Droit européen du divorce. European Divorce Law. Éd. S. Corneloup. Paris 2013, s. 137 i n.; M.C. Domínguez Guillén, O. Riquezes Contreras: Algunas consideraciones sobre el adulterio como causal de divorcio (especial referencia a los antecedents históricos). „Revista Venezolana de Legislación y Jurisprudencia” 2013, núm. 2, s. 281-284 ; E. Ör ücü: Changing concept of „family” and challenges for law: Turkey. In: European Family Law. Vol. 2: The Changing Concept of Family and Challenges for Domestic Family Law. Ed. J.M. Scherpe. Cheltenham, Northhampton, 2016, s. 348; I. Schwenzer, T. Keller: The changing concept of ,family" and challenges for law: Switzerland. In: European Family Law. Vol. 2: The Changing Concept of Family and Challenges for Domestic Family Law. Ed. J.M. Scherpe..., s. 316.

${ }^{2}$ W tym przypadku termin „postępowanie” należy rozumieć szeroko, tak by możliwe było objęcie nim wszelkich sposobów rozwiązania małżeństwa. 
Odnoszac się do zaprezentowanej w glosowanym orzeczeniu argumentacji, wskazać należy, że nie zasługuje na aprobatę pogląd, zgodnie z którym art. $57 \S 1$ k.r.o., nakazujacy sądowi orzekającemu o rozwiązaniu małżeństwa dokonanie rozstrzygnięcia w przedmiocie winy w rozkładzie pożycia, ma charakter jedynie procesowy. Należałoby raczej przyjąć, że jest to regulacja, która można zaliczyć do znanej nauce prawa cywilnego (zarówno materialnego, jak i procesowego) oraz orzecznictwu kategorii przepisów o podwójnej naturze - materialnej i procesowej ${ }^{3}$. Można w tym miejscu jedynie nadmienić, że specyfika tego rodzaju unormowań nie ujawnia się w tych przypadkach, gdy sąd stosuje jako właściwe prawo merytoryczne obowiązujące $\mathrm{w}$ siedzibie forum, lecz dopiero wówczas, gdy normy proceduralne i normy prawa wskazanego miarodajną normą kolizyjną pochodzą z dwóch różnych systemów prawnych.

Przejawy procesowej natury art. $57 \S 1$ k.r.o. można więc sprowadzić do nałożonego na sąd polski (do którego adresowane są obowiązujące na terytorium RP normy proceduralne) obowiązku orzeczenia o winie w rozkładzie pożycia małżonków (w zerwaniu więzi małżeńskich) w wyroku rozwodowym. Oznacza to, że polski sąd wydajacy wyrok w sprawie o rozwód, bez względu na to, które prawo pełni funkcję statutu rozwiązania małżeństwa, stosuje art. 57 § 1 k.r.o. w zakresie jego treści procesowej ${ }^{4}$, zamieszczając $\mathrm{w}$ orzeczeniu kończącym sprawę $\mathrm{w}$ danej instancji rozstrzygnięcie w przedmiocie winy, albo też odstępuje od takiego rozstrzygnięcia, jeżeli spełnione są przesłanki art. $57 \S 2$ k.r.o. Wówczas takie zagadnienia, jak pojęcie winy, ewentualne jej stopniowanie oraz katalog zachowań małżonka, które noszą znamiona zawinienia, oceniane są przez sąd na podstawie prawa wskazanego normą kolizyjna z art. 54 p.p.m. Jednak w przypadku, gdy miarodajne prawo właściwe nie przewiduje orzekania o winie ani nie nadaje winie w rozkładzie pożycia jakiejkolwiek doniosłości w kontekście podstaw rozwiązania małżeństwa z uwagi na służebna rolę norm proceduralnych względem regulacji prawa materialnego, stosowanie omawianego przepisu - w takim zakresie, w jakim chodzi o jego procesowa naturę - staje się bezprzedmiotowe. Na marginesie można zauważyć, że ta ostatnia uwaga zdaje się zgodna z poglądem wyrażonym przez Sąd Najwyższy w glosowanym orzeczeniu.

${ }^{3} \mathrm{~W}$ literaturze polskiej zob. m.in. W. Skierkowska: Międzynarodowe postępowanie cywilne $w$ sprawach alimentacyjnych. Warszawa 1972, s. 122 . W literaturze obcej: M. Andrae: Internationales Familienrecht. Berlin 2006, s. 212 i n.; G. Hohloch, in: Erman BGB Kommentar, 2017, s. 6069; P. Winkler von Mohrenfels: Verordnung (EU) Nr. 1259/2010. In: Münchener Kommentar zum Bürgerlichen Gesetzbuch. Bd. 10: Internationales Privatrecht I. Europäisches Kollisionsrecht. Einführungsgesetz zum Bürgerlichen Gesetzbuche (Art. 1-240). Hrsg. J. v. Hein. München 2015, s. 1215.

${ }^{4}$ W. Skierkowska: Międzynarodowe postępowanie..., s. 123. 
Natomiast materialnoprawny charakter analizowanego przepisu przejawia się w tym, że sąd (lub inny organ obcego państwa powołany do rozpatrywania spraw o rozwiąanie małżeństwa) stosujący w sprawie rozwodowej jako właściwe prawo polskie jest zobowiąany do ustalenia przed wydaniem orzeczenia rozwiązującego małżeństwo, czy i który $\mathrm{z}$ małżonków ponosi winę $\mathrm{w}$ rozkładzie pożycia. Wina (w postaci wyłącznej winy jednego z małżonków) stanowi bowiem, zgodnie z art. 56 $\S 3$ k.r.o., negatywną przesłankę orzeczenia rozwodu (zob. poniżej). Z tego też względu dokonanie przez sąd odpowiednich ustaleń przed wydaniem rozstrzygnięcia zgodnego $\mathrm{z}$ art. $57 \S 1$ k.r.o. jest niezbędne. Oznacza to, że - co pozostaje w sprzeczności ze stanowiskiem Sądu Najwyższego zaprezentowanym $\mathrm{w}$ glosowanym orzeczeniu - sąd (lub organ) innego państwa orzekający w sprawie o rozwód, w której w roli statutu rozwiązania małżeństwa występuje prawo polskie, stosuje art. $57 \S 1$ k.r.o. w celu ustalenia, czy nie zachodzi negatywna przesłanka rozwodu, jednak stosownego rozstrzygnięcia dokonuje w ramach procesowych przewidzianych $\mathrm{w}$ legis fori processualis. Tym samym w braku w obcym prawie procesowym odpowiedniej regulacji, pozwalającej zamieścić w sentencji orzeczenia rozstrzygnięcia o winie (lub w przypadku wyraźnego zaka$\mathrm{zu}$ ), sąd orzekający jest zobowiązany do odnalezienia w wiążącej go procedurze takiego instrumentu, który pozwala na realizację art. 57 k.r.o. ${ }^{5}$

Można również rozważyć, w ślad za wzmiankowaną w glosowanym postanowieniu argumentacja pełnomocnika powódki, czy w sferze materialnoprawnej art. $57 \S 1$ k.r.o. powinien być traktowany jako przepis wymuszający swoje zastosowanie (art. 8 ust. 1 p.p.m., błędnie oznaczony jako art. 8 ust. 2 p.p.m.) i jako taki być stosowany w każdej sprawie, w której sąd polski orzeka o rozwodzie, bez względu na to, jakie prawo jest właściwe. Należałoby się opowiedzieć przeciwko takiemu odczytywaniu treści omawianego przepisu, a to z tego względu, że art. $57 \S 1$ nie spełnia przecież przesłanek określonych $\mathrm{w}$ art. 8 ust. 1 p.p.m. W literaturze przedmiotu podkreśla się, że do przepisów wymuszających swoje zastosowanie można zaliczyć jedynie te, które mają kluczowe znaczenie dla ochrony porządku publicznego państwa, i ze względu na swój cel lub charakter znajduja zastosowanie niezależnie od prawa właściwego dla danej sytuacji życiowej ${ }^{6}$. Chodzi tu więc o normy o szczególnej doniosłości

${ }^{5}$ Co może polegać np. na zamieszczeniu stosownych rozważań w uzasadnieniu orzeczenia.

${ }^{6}$ M. Pazdan: Przepisy szczególne o dziedziczeniu gospodarstw rolnych z kolizyjnoprawnego punktu widzenia. W: Zagadnienie prawa cywilnego, samorzadowego i rolnego. Pamięci Profesora Waleriana Pańki. Red. A. Agopszowicz, T. Kurowska, M. Pazdan. Katowice 1993, s. 188 i n.; K. Przybyłowski: Prawo prywatne międzynarodowe. Część ogólna. Lwów 1935, s. 168; M. Tom aszewski, w: Prawo prywatne międzynarodo- 
danego systemu prawnego, które służą ochronie fundamentalnych interesów publicznych ${ }^{7}$. Wskazuje się też, że ingerencja tego rodzaju przepisów w oceniany stosunek prawny (sytuację faktyczną) powinna mieć charakter wyjątkowy, a jej dopuszczalność ma wynikać z tak ważnych powodów, że ingerencja ta jest utożsamiana z ochroną ordre public ${ }^{8}$.

Uwzględniając wyżej przytoczone cechy konstytutywne przepisów wymuszających swoje zastosowanie, należy uznać, że art. $57 \S 1$ k.r.o. nie spełnia przesłanek tego rodzaju regulacji. Nie ulega przecież wątpliwości, że w polskiej regulacji przyczyn rozwodu wina nie odgrywa kluczowej roli, gdyż rozwiązanie małżeństwa może nastąić jedynie wówczas, gdy występuja przyczyny o charakterze obiektywnym, pozwalające przyjąć, że między małżonkami nastąpił zupełny i trwały rozkład pożycia (art. 56 $\S 1$ k.r.o. $)^{9}$. Istniejące u podstaw rozkładu pożycia małżonków okoliczności moga mieć zarówno charakter zawiniony, jak i niezawiniony przez małżonka ${ }^{10}$, a ich ujmowanie $\mathrm{w}$ dwie grupy (przyczyn zawinionych i niezawinionych), co często spotyka się w literaturze, ma co najwyżej znaczenie porządkujace. Innymi słowy, rozwód zgodnie z prawem polskim jest dopuszczalny jedynie w przypadku wystąpienia zupełnego i trwałego rozkładu pożycia małżonków, bez względu na to, czy do ustania poży-

we. Komentarz. Red. J. Poczobut. Warszawa 2017, s. 237 i n.; M.A. Zachariasiewicz, w: Prawo prywatne międzynarodowe. Komentarz. Red. M. Pazdan. Warszawa 2018, s. 156.

${ }^{7}$ M. Mataczyński: Przepisy wymuszajace swoje zastosowanie $w$ prawie prywatnym międzynarodowym. Kraków 2005, s. 113 i n.; M.A. Zachariasiewicz, w: Prawo prywatne..., Red. M. Pazdan, s. 160; Eadem: O potrzebie wskazania w nowej ustawie o prawie prywatnym międzynarodowym podstawy stosowania przepisów wymuszajacych swoje zastosowanie. „Problemy Prawa Prywatnego Międzynarodowego” 2010, T. 7, s. 9 i n.

${ }^{8}$ M. Sośniak: Klauzula porzadku publicznego $w$ prawie prywatnym międzynarodowym. Warszawa 1961, s. 10 i n.; M. Wojewoda: Mandatory Rules In Private International Law - with Reference to Mandatory System under the Rome Convention on the Law applicable to the Contractual Obligations. „Maastricht Journal of European and Comparative Law" 2000, s. 193; Idem: Zakres prawa właściwego dla zobowiazań umownych. Nowa regulacja kolizyjna w konwencji rzymskiej. Warszawa 2007, s. 191 i n.; M.A. Zachariasiewicz, w: Prawo prywatne..., Red. M. Pazdan, s. 159; Eadem, w: „System Prawa Prywatnego”. T. 20A: Prawo prywatne międzynarodowe. Red. M. Pazdan. Warszawa 2014, s. 437 i n.

${ }_{9}$ Por. m.in. J. Górecki: Wina rozwodu a moralność (z rozważań nad zasadami rekryminacji). „Państwo i Prawo” 1965, z. 1, s. 27; A. Olejniczak: Materialnoprawne przestanki udzielenia rozwodu. Poznań 1980, s. 23 i n.; K. Pia secki: Prawo matżeńskie. Warszawa 2011, s. 230-233; T. Sokołowski, w: „System Prawa Prywatnego”. T. 11: Prawo rodzinne i opiekuńcze. Red. T. Smyczyński. Warszawa 2014, s. 570 i n.

${ }_{10}$ B. Czech, w: Kodeks rodzinny i opiekuńczy. Komentarz. Red. K. Piasecki. Warszawa 2011, s. 383; J. Ignatowicz: Rozwód po nowelizacji. Art. 56-61 k.r.o. Komentarz. Warszawa 2009, s. 13 i n.; K. Piasecki: Prawo matżeńskie..., s. 230 i n. 
cia doszło wskutek okoliczności, które można zarzucić któremukolwiek $\mathrm{z}$ małżonków ${ }^{11}$. Winie (i to tylko w postaci wyłącznej winy jednego z małżonków) przypisano doniosłość wyłącznie w katalogu negatywnych przesłanek (przeszkód) rozwodu (art. $56 \S 3$ k.r.o.) ${ }^{12}$. W polskiej literaturze oraz orzecznictwie istnieje zgoda co do tego, że wina w rozkładzie pożycia odgrywa tylko posiłkową rolę wśród przesłanek rozwiązania małżeństwa ${ }^{13}$, stanowiąc podstawę do oddalenia powództwa o rozwód w stanie faktycznym odpowiadajacym dyspozycji art. $56 \S 3$ k.r.o. To ostatnie unormowanie stanowi więc jedyny przypadek, w którym polski ustawodawca, określając podstawy do rozwiązania małżeństwa, sięgnął do przesłanki winy $^{14}$. Nie należy zapominać, że statuowana w art. $56 \S 3$ k.r.o. zasada rekryminacji doznaje dwóch istotnych wyjątków ${ }^{15}$, pozwalających na orzeczenie rozwodu nawet wówczas, gdy powód jest wyłącznie winny rozkładowi pożycia. Można więc zasadnie przyjąć, że w przypadku konfliktu dwóch wartości: z jednej strony, ochrony małżonka niewinnego, a z drugiej, umożliwienia rozwiedzionym małżonkom założenia pełnej, prawidłowo funkcjonujacej rodziny, polski system prawny co do zasady wyżej stawia drugą $\mathrm{z}$ nich ${ }^{16}$. Trzeba też raz jeszcze przypomnieć, że sięganie do art. $56 \S 3$ k.r.o. jako podstawy oddalenia powództwa jest dopuszczalne tylko wtedy, gdy sąd stwierdzi, że między małżonkami zaistniał zupełny i trwały rozkład pożycia, a więc wówczas, gdy spełniona jest pozytywna przesłanka rozwiązania małżeństwa (art. $56 \S 1$ k.r.o.) ${ }^{17}$. Co więcej, kierowany do sąu nakaz wynikający z art. $57 \S 1$ k.r.o. ma charakter względny w tym znaczeniu, że na wniosek stron sąd może odstapić od orzekania o winie (art. $57 \S 2$ k.r.o.) ${ }^{18}$. W tym ostatnim przypadku orzekanie w sentencji wyroku o winie jest niedopuszczalne ${ }^{19}$.

Jedynie już na marginesie można dodać, że tym samym brak jest też podstaw do przyjęcia, że art. $57 \S 1$ k.r.o. miałby być uwzględniany na

${ }^{11}$ G. Jędrejek: Kodeks rodzinny i opiekuńczy. Komentarz. Wolters Kluwer 2017, s. 384 i n.; A. Olejniczak: Materialnoprawne przestanki..., s. 113 i n.

${ }^{12}$ W. Stojanowska, w: „System Prawa Prywatnego”. T. 11..., Red. T. Smyczyński, s. 646; A. Szpunar: Rozwód na żqdanie małżonka wytacznie winnego rozkładu. W: Prace z prawa cywilnego wydane dla uczczenia pracy naukowej profesora Józefa Stanistawa Piatowskiego. Red. B. Kord a siewicz, E. Łętowska. Warszawa 1985, s. 325.

${ }_{13}$ A. Olejniczak, w: Kodeks rodzinny i opiekunczy. Red. H. Dolecki, T. Sokołowski. Warszawa 2013, s. 421.

${ }^{14}$ Ibidem, s. 432.

15 J. Ignatowicz: Rozwód..., s. 27.

${ }_{16}$ A. Olejniczak, w: Kodeks rodzinny i opiekuńczy. Red. H. Dolecki, T. Sokołowski..., s. 433.

${ }^{17}$ B. Czech, w: Kodeks rodzinny..., Red. K. Piasecki, s. 404.

18 K. Piasecki: Prawo matżeńskie..., s. 234.

19 J. Winiarz, w: Kodeks rodzinny i opiekuńczy. Komentarz. Red. K. Pietrzykowski. Warszawa 2012, s. 551. 
podstawie normy kolizyjnej będacej odpowiednikiem art. 8 ust. 2 p.p.m. ${ }^{20}$ przez sąd (organ) innego państwa w każdym przypadku, gdy chodziłoby o rozwód obywatela polskiego, a prawem właściwym do oceny rozwiązania małżeństwa byłoby prawo obce. Brak jest bowiem de lege lata uzasadnienia dla nadawania polskiej regulacji winy w rozkładzie pożycia tak dalece idącej doniosłości z punktu widzenia interesów polskiego porządku prawnego, aby wynikający z art. $57 \S 1$ k.r.o. obowiązek ustalenia przez sąd orzekający o rozwiązaniu małżeństwa, czy i który z małżonków ponosi winę w rozkładzie pożycia, przeważał nad regulacjami prawa ojczystego drugiego z małżonków oraz nad prawem występującym w roli statutu rozwiązania małżeństwa.

Jak już wskazano, w niektórych systemach prawnych stwierdzona $\mathrm{w}$ postępowaniu o rozwiązanie małżeństwa wina $\mathrm{w}$ zerwaniu więzi małżeńskich nie pozostaje bez wpływu na ocenę dalszych skutków rozwodu. W szczególności odnosi się to do obowiązku alimentacyjnego między byłymi małżonkami, którego powstanie oraz czas trwania mogą być uzależnione od uprzedniej nagannej oceny zachowania małżonka przed rozwiązaniem małżeństwa. Sąd rozpatrujący żądanie rozwiedzionego małżonka w odniesieniu do alimentów może więc napotkać trudności $\mathrm{w}$ takim przypadku, gdy $\mathrm{w}$ roli statutu alimentacyjnego występuje system prawny przypisujący określone znaczenie winie, a w roli statutu rozwiązania małżeństwa - prawo, które nie przewiduje możliwości orzeczenia o winie w wyroku rozwodowym czy wręcz wprowadza zakaz rozstrzygania $\mathrm{w}$ tej kwestii. Z tego rodzaju sytuacją spotkał się Sąd Apelacyjny orzekajacy w sprawie, w której zostało wydane glosowane orzeczenie, a w której sądy obu instancji przyjęły, że o rozwiązaniu małżeństwa rozstrzyga prawo norweskie, nieprzewidujące możliwości ustalania zawinienia małżonków w rozkładzie ich pożycia, a o roszczeniach alimentacyjnych małżonka należnych po rozwodzie decyduje prawo polskie, które w tej mierze przywiązuje daleko idące znaczenie stwierdzonej przy rozwiązaniu małżeństwa winie. Z tego też względu Sąd Apelacyjny powziął wątpliwość co do roli, jaką może odgrywać art. $57 \S 1$ k.r.o. $\mathrm{w}$ przypadku, gdy na podstawie normy kolizyjnej z art. 54 p.p.m. dochodzi do wskazania prawa obcego. Poza zakresem niniejszych rozważań, jak już wspomniano na wstępie, pozostaje ocena tego, czy prawidłowo doszło do odszukania przez sądy orzekające w sprawie prawa właściwego

${ }^{20} \mathrm{Na}$ temat przepisów wymuszających swoje zastosowanie prawa obcego zob. m.in. M. Mataczyński: Obce przepisy wymuszajace swoje zastosowanie. Rozważania na tle art. 7 konwencji rzymskiej oraz orzecznictwa sqdów niemieckich. „Kwartalnik Prawa Prywatnego" 2001, z. 2, s. 113; M.A. Zachariasiewicz, w: „System Prawa Prywatnego". T. 20A..., Red. M. Pazdan, s. 454 i n. 
do oceny roszczeń alimentacyjnych powódki i, co za tym idzie, czy rzeczywiście zachodzi wskazana wyżej rozbieżność między systemami prawnymi odgrywającymi role miarodajnych statutów. Należałoby się jednak zastanowić, czy w prawie prywatnym międzynarodowym istnieje tego rodzaju instrument, który pozwoliłby należycie uwzględnić stanowiska wchodzących w grę porządków prawnych.

Zabiegiem pozwalającym usunąć rozbieżności pomiędzy stosowanymi jednocześnie (lub kolejno) systemami prawnymi ${ }^{21}$ jest dostosowanie ${ }^{22}$. Polega ono nie tyle na zmianie treści norm materialnoprawnych, ile na modyfikacji sposobu ich stosowania, tak aby uzyskane rozstrzygnięcie było logicznie spójne i słuszne ${ }^{23}$. Wskazać też należy, że do istoty dostosowania należy działanie punktowe, a więc jedynie w precyzyjnie wytyczonym obszarze, w którym zostały zidentyfikowane rozbieżności ${ }^{24}$.

Wskazuje się również, że dostosowanie stosowane być musi bardzo ostrożnie, tak aby nie wypaczyć sensu prawa właściwego do oceny danego aspektu rozpatrywanej sprawy. Oznacza to, że gdyby dostosowanie było dokonywane w sytuacji, w której w roli statutu rozwiązania małżeństwa występuje prawo, które hołduje rozwodowi z przyczyn obiektywnych, niezależnych od winy małżonków, albo wręcz jako zasadę przyjmuje dopuszczalność rozwodu na wniosek małżonków, prowadzone na użytek rozstrzygnięcia o obowiązku alimentacyjnym rozważania dotyczace nagannej postawy małżonków nie mogą w żaden sposób odnosić skutku względem samego rozwiązania małżeństwa.

Wydaje się nie budzić wątpliwości, że sąd orzekający o obowiązku alimentacyjnym między rozwiedzionymi małżonkami może samodzielnie, na potrzeby rozstrzyganej sprawy, dokonać oceny zachowania stron przed rozwiązaniem małżeństwa i ustalić, czy noszą one znamiona winy. Brak też podstaw, aby formułować zarzuty pod adresem wyroku rozwodowego, w którego uzasadnieniu zamieszczono rozważania odnoszące się do ujemnie ocenianych zachowań małżonka, mimo że prawo wskazane normą kolizyjną z art. 54 p.p.m. nie uzależnia rozwiązania małżeństwa

${ }^{21}$ W odróżnieniu od dostosowania dokonywanego na płaszczyźnie kolizyjnoprawnej, polegającego na modyfikacji zakresów norm kolizyjnych.

${ }^{22}$ D. Looschelders: Die Anpassung im internationalen Privatrecht: zur Methodik der Rechtsanwendung in Fällen mit wesentlicher Verbindung zu mehreren nicht miteinander harmonierenden Rechtsordnungen. Heidelberg 1995, s. 263.

${ }^{23} \mathrm{Na}$ temat dostosowania w polskim prawie prywatnym międzynarodowym zob. m.in. M. Pazdan: Prawo prywatne międzynarodowe. Warszawa 2017, s. 86; K. Sznajder-Peroń, w: „System Prawa Prywatnego”. T. 20A..., Red. M. Pazdan, s. 537 i n.; Eadem, w: Prawo prywatne..., Red. M. Pazdan, s. 74 i n.

${ }^{24}$ D. Looschelders: Die Anpassung..., s. 191; K. Sznajder-Peroń, w: Prawo prywatne..., Red. M. Pazdan, s. 77; Eadem, w: „System Prawa Prywatnego”. T. 20A..., Red. M. Pazdan, s. 538-539. 
lub jego skutków od stwierdzonej w postępowaniu o rozwód winy ${ }^{25}$, jeżeli rozważania te zostały przeprowadzone $\mathrm{w}$ związku $\mathrm{z}$ ustaleniem istnienia przesłanek obowiązku alimentacyjnego.

\section{Bibliografia}

Andrae M.: Internationales Familienrecht. Berlin 2006.

Antokolskaia M.: Divorce law in a European perspective. In: European Family Law. Vol. 3: Family Law in European Perspective. Ed. J.M. Scherpe. Cheltenham, Northampton, 2016.

Bernand Y., in: La rupture de marriage en droit compare. Éd. H. Fulchiron. Paris 2015.

Bosse-Platière H.: Le droit français du divorce. In: Droit européen du divorce. European Divorce Law. Éd. S. Cor neloup. Paris 2013.

Czech B., w: Kodeks rodzinny i opiekuńczy. Komentarz. Red. K. Piasecki. Warszawa 2011.

Domínguez Guillén M.C., Riquezes Contreras O.: Algunas consideraciones sobre el adulterio como causal de divorcio (especial referencia a los antecedents históricos). „Revista Venezolana de Legislación y Jurisprudencia” 2013, núm. 2.

Franzina P.: The law applicable to divorce and legal separation under Regulation (EU) no. 1259/2010 of 20 december 2010. „Cuadernos de Derecho Transnacional" 2011, no. 2.

Górecki J.: Wina rozwodu a moralność (z rozważań nad zasadami rekryminacji). „Państwo i Prawo” 1965, z. 1.

Hohloch G., in: Erman BGB Kommentar, 2017.

Ignatowicz J.: Rozwód po nowelizacji. Art. 56-61 k.r.o. Komentarz. Warszawa 2009.

Jędrejek G.: Kodeks rodzinny i opiekuńczy. Komentarz. Wolters Kluwer 2017.

Looschelders D.: Die Anpassung im internationalen Privatrecht: zur Methodik der Rechtsanwendung in Fällen mit wesentlicher Verbindung zu mehreren nicht miteinander harmonierenden Rechtsordnungen. Heidelberg 1995.

Mataczyński M.: Obce przepisy wymuszajace swoje zastosowanie. Rozważania na tle art. 7 konwencji rzymskiej oraz orzecznictwa sqdów niemieckich. „Kwartalnik Prawa Prywatnego” 2001, z. 2.

Mataczyński M.: Przepisy wymuszajqce swoje zastosowanie w prawie prywatnym międzynarodowym. Kraków 2005.

${ }_{25}$ Tak J. Winiarz, w: Kodeks rodzinny i opiekuńczy..., Red. K. Pietrzykowski, s. 551 . 
Olejniczak A.: Materialnoprawne przestanki udzielenia rozwodu. Poznań 1980.

Olejniczak A., w: Kodeks rodzinny i opiekuńczy. Red. H. Dolecki, T. Sokołowski. Warszawa 2013.

Ör ücü E.: Changing concept of „family” and challenges for law: Turkey. In: European Family Law. Vol. 2: The Changing Concept of Family and Challenges for Domestic Family Law. Ed. J.M. Scherpe. Cheltenham, Northhampton, 2016.

Pazdan M.: Prawo prywatne międzynarodowe. Warszawa 2017.

Pazdan M.: Przepisy szczególne o dziedziczeniu gospodarstw rolnych z kolizyjnoprawnego punktu widzenia. W: Zagadnienie prawa cywilnego, samorzadowego i rolnego. Pamięci Profesora Waleriana Pańki. Red. A. Agopszowicz, T. Kurowska, M. Pazdan. Katowice 1993.

Piasecki K.: Prawo matżenskie. Warszawa 2011.

Przybyłowski K.: Prawo prywatne międzynarodowe. Część ogólna. Lwów 1935.

Schwenzer I., Keller T.: The changing concept of „family” and challenges for law: Switzerland. In: European Family Law. Vol. 2: The Changing Concept of Family and Challenges for Domestic Family Law. Ed. J.M. Scherpe. Cheltenham, Northhampton, 2016.

Skierkowska W.: Międzynarodowe postepowanie cywilne $w$ sprawach alimentacyjnych. Warszawa 1972.

Sokołowski T., w: „System Prawa Prywatnego”. T. 11: Prawo rodzinne i opiekuńcze. Red. T. Smyczyński. Warszawa 2014.

Sośniak M.: Klauzula porzadku publicznego $w$ prawie prywatnym międzynarodowym. Warszawa 1961.

Stojanowska W., w: „System Prawa Prywatnego”. T. 11: Prawo rodzinne i opiekuńcze. Red. T. Smyczyński. Warszawa 2014.

Sznajder-Peroń K., w: Prawo prywatne międzynarodowe. Komentarz. Red. M. Pazdan. Warszawa 2018.

Sznajder-Peroń K., w: „System Prawa Prywatnego”. T. 20A: Prawo prywatne międzynarodowe. Red. M. Pazdan. Warszawa 2014.

Szpunar A.: Rozwód na żqdanie matżonka wytacznie winnego rozktadu. W: Prace $z$ prawa cywilnego wydane dla uczczenia pracy naukowej profesora Józefa Stanistawa Piqtowskiego. Red. B. Kordasiewicz, E. Łętowska. Warszawa 1985.

Tomaszewski M., w: Prawo prywatne międzynarodowe. Komentarz. Red. J. Poczobut. Warszawa 2017.

Winiarz J., w: Kodeks rodzinny $i$ opiekuńczy. Komentarz. Red. K. Pietrzykowski. Warszawa 2012.

Winkler von Mohrenfels P.: Verordnung (EU) Nr. 1259/2010. In: Münchener Kommentar zum Bürgerlichen Gesetzbuch. Bd. 10: Internationales Privatrecht I. Europäisches Kollisionsrecht. Einführungsgesetz zum Bürgerlichen Gesetzbuche (Art. 1-240). Hrsg. J. v. Hein. München 2015. 
Wojewoda M.: Mandatory Rules In Private International Law - with Reference to Mandatory System under the Rome Convention on the Law applicable to the Contractual Obligations. „Maastricht Journal of European and Comparative Law" 2000.

Wojewoda M.: Zakres prawa właściwego dla zobowiazań umownych. Nowa regulacja kolizyjna w konwencji rzymskiej. Warszawa 2007.

Zachariasiewicz M.A.: O potrzebie wskazania $w$ nowej ustawie o prawie prywatnym międzynarodowym podstawy stosowania przepisów wymuszajacych swoje zastosowanie. „Problemy Prawa Prywatnego Międzynarodowego” 2010, T. 7.

Zachariasiewicz M.A., w: Prawo prywatne międzynarodowe. Komentarz. Red. M. Pazdan. Warszawa 2018.

Zachariasiewicz M.A., w: „System Prawa Prywatnego”. T. 20A: Prawo prywatne międzynarodowe. Red. M. Pazdan. Warszawa 2014. 